\title{
Amino Acids Content in Mangosteen Fruit as Affected by Tree Ages
}

\author{
Eko Setiawan \\ Faculty of Agriculture, University of Trunojoyo Madura, \\ Jl. Raya Telang PO Box 2, Kamal, Bangkalan, Madura, Indonesia \\ Corresponding author: e_setiawan@trunojoyo.ac.id \\ Cellular phone number: +62 - 82332806588
}

Diterima 7 Februari 2017/Disetujui 7 Maret 2017

\begin{abstract}
We investigated the effect of tree age on the content and composition of amino acids in mangosteen (Garcinia mangostana L.) fruit (aril) harvested from a commercial orchard in Bogor, Indonesia were studied in 2012. Mangosteen trees of 3 different ages (young, 20 years; middle-aged, 35 years; old, 50 years of age trees) were sampled. Fruits at the mature green stage harvested from each trees. For all tree ages, the main amino acids in the aril were $\gamma$-aminobutyric acid and alanine. The total amino acid content was higher in fruits harvested from young trees than in fruits harvested from middleaged and old trees.
\end{abstract}

Key words: amino acids, content, GABA, mangosteen.

\section{ABSTRAK}

Kita meneliti perbedaan kandungan dan komposisi asam amino pada buah manggis yang dipanen dari pohon yang berbeda umur dari kebun Manggis di Bogor pada tahun 2012. Pohon manggis dengan umur yang berbeda (muda, sekitar 20 tahun; sedang, sekitar umur 35 tahun; dan tua, sekitar 50 tahun)dipilih untuk diambil buahnya. Buah dari tiap pohon dipanen pada kondisi masak hijau spot kuning-merah. Pada buah dari semua umur pohon, asam amino yang dominan adalah $\gamma$ aminobutyric acid dan alanine. Total kandungan asam amino tertinggi terdapat pada buah yang dipetik dari pohon umur muda dari pada buah yang dipetik dari pohon umur sedang dan tua.

Kata kunci: asam amino, GABA, kandungan, manggis

\section{INTRODUCTION}

Garcinia mangostana L. (Hypericaceae alternatively known as Clusiaceae and Guttiferae) plant is a tropical evergreen tree, believed to have originated in the Sunda Islands and the Moluccas (Misra et al., 2009). International market demand for mangosteen fruit is increasing. In recent years, Indonesian mangosteen has been export not only to Taiwan, Hong Kong, and Singapore, but also to Europe and the Middle East (Setiawan and Poerwanto, 2008). The quality of mangosteen fruit generally is evaluate using Codex Stan 204-2007, based on fruit weight and diameter, absence of scars, and an undamaged and fresh green-colored calyx. However, heavy and large fruit is usually consider to be of high quality (Diczbalis, 2009; Setiawan et al., 2012b). The overall taste and flavor of many fruits are known affect by a number of factors, including the content and composition of sugars, non-volatile organic acids, and amino acids (Barboni et al., 2010). Mangosteen fruit is usually harvest at different stages according to color, and its shelf life is very short (Setiawan, 2013). To maximize shelf life, fruit for export is best harvest at the mature green stage (yellowish white with scattered pink spots) (Palapol et al.,
2009). However, detailed analysis of the content and composition of sugars, organic acids, and amino acids in mangosteen fruit (aril) harvested at the mature green stage is lacking and its content relations with $\mathrm{N}$ content in leaves (Setiawan, 2014).

At present, the fruit rind of this plant has long been used as a traditional medicine for treatment of abdominal pain, diarrhea, dysentery, infected wound, suppuration, and chronic ulcer, exhibits antioxidant, anti-tumoral, antiinflammatory, anti-allergic, antibacterial and antifungal activities because contain a variety of phenolic compounds such as condensed tannins, anthocyanins, xanthones and their derivatives (Pothitirat and Gritsanapan, 2009). Khalid et al. (2012) observed that the fruit quality of 'Kinnow' mandarin differed according to tree age, and that the total sugar (especially reducing sugar) and acid contents were higher in fruits harvested from 18-year-old trees than in fruits harvested from 3-year-old trees. However, the quality (content of sugars, organic acids, and amino acids) of mangosteen fruits among tree age have not previously been elucidate. In the present study, we investigated the content of amino acids in mangosteen fruit (aril) harvested at the mature green stage as affected by different tree age. 


\section{MATERIALS AND METHODS}

\section{Plant Materials}

We sampled mangosteen trees are the same sibling of 3 different ages (young, putative 20 years old; middle-aged, putative 35 years old; and old, putative 50 years old; $n=5$ per age), growing in a commercial orchard in Bogor, Indonesia were studied in 2012-2013. Tree height, width of the tree canopy, and circumference of the trunk (measured at $1 \mathrm{~m}$ from the ground) for young, middle-aged, and old trees were approximately $6.8 \mathrm{~m}, 9.2 \mathrm{~m}$, and $10.6 \mathrm{~m} ; 7.1 \mathrm{~m}, 7.3 \mathrm{~m}$, and $9.5 \mathrm{~m}$; and $51 \mathrm{~cm}, 62 \mathrm{~cm}$, and $76 \mathrm{~cm}$, respectively. The canopy of each tree was divided into 9 sectors (fruit position) according to tree height (bottom, middle, top) and width (inner, center, outer) as follows: Sector 1, inner bottom; Sector 2, center bottom; Sector 3, outer bottom; Sector 4, inner middle; Sector 5, center middle; Sector 6, outer middle; Sector 7, inner top; Sector 8, center top; and Sector 9, outer top (Figure 1). One fruit was harvested from each sector in mid-October, 2012 at the mature green stage fruit (yellowish white with scattered pink spots) from each tree age. Each fruit was separate into the pericarp, aril, and seed. The fresh aril was weighed and dried in an oven for 4 days at $70{ }^{\circ} \mathrm{C}$. After measurement of the dry weight, the fruit was ground into a powder using a mill.

\section{Extraction of Amino Acids from the Aril}

Before extraction, the aril powder was dried in oven at $70{ }^{\circ} \mathrm{C}$. Approximately $500 \mathrm{mg}$ of dried aril powder was placed in a flask, and $20 \mathrm{~mL}$ of $80 \%$ ethanol was added. The mixture was shaken in a water bath for $20 \mathrm{~min}$ at $50{ }^{\circ} \mathrm{C}$, and filtered to extract sugars, organic acids, and amino acids. This extraction procedure was repeated 3 times, and all of the filtered extracts were combined. The extracts were dried under vacuum at $45^{\circ} \mathrm{C}$, and the residue was dissolved in 10 $\mathrm{mL}$ of distilled water and filtered. Subsequently, $2 \mathrm{~mL}$ of the filtrate was passed through a column of Amberlite CG 120 cation $\left(\mathrm{H}^{+}\right)$ion-exchange resin, joined to a column of Amberlite IRA 45 anion $\left(\mathrm{OH}^{-}\right)$ion-exchange resin, and eluted with distilled water. The volume was then made up to $50 \mathrm{~mL}$.

\section{Amino Acid Analysis}

The amino acid fraction was obtained by eluting the substances adsorbed onto the Amberlite CG 120 cation $\left(\mathrm{H}^{+}\right)$ ion-exchange resin with $50 \mathrm{~mL}$ of $2 \mathrm{~N} \mathrm{NH}_{4} \mathrm{OH}$. The eluate was evaporated to dryness at $45{ }^{\circ} \mathrm{C}$, and dissolved in $5 \mathrm{~mL}$ of distilled water. Following centrifugation at $7 \times 10^{3} \mathrm{rpm}$ for $10 \mathrm{~min}$, the supernatants were analyzed using fully automated HPLC (Hitachi, L-8500). Amino acids were identified by comparing the retention times with those of authentic standards obtained under the same analytical conditions. The content of each amino acid was then calculated.

\section{Statistical Analysis}

A two-way analysis of variance (ANOVA) was performed to test for significant differences in fruit quality among tree ages. Means were compared using Duncan's Multiple Range Test. All statistical tests were carried out using SPSS version 16.0 (IBM SPSS Inc., Chicago). Differences with $p$-values $<0.05$ were considered significant.

\section{RESULTS AND DISCUSSION}

From the analysis of different mangosteen tree age, sixteen different amino acids were found in mangosteen fruits (aril), including $\gamma$-aminobutyric acid (GABA), alanine (ALA), isoleucine (ILE), valine (VAL), and glycine (GLY) (Table 1 and 2). The representative chromatograms of amino acid standard, mangosteen fruit (aril) extract are shown in Figure 2. $\gamma$-Aminobutyric Acid (GABA) is a four-carbon non-protein amino acid that is present in the free amino acid pools of most prokaryotic and eukaryotic organisms. GABA is a non-protein amino acid that accumulates in plant tissues in response to a variety of environmental stresses (Barbosa et al., 2010). In plants, GABA accumulation induced by salt stress result from the activation of glutamate decarboxylase (GAD), whereas GAD is cytoplasmic enzyme dependent on calcium and calmodulin for activation (Huang et al., 2011; Xing et al., 2007; Barbosa et al., 2010). For all tree ages, GABA and ALA were the most abundant amino acids; the other amino acids were detect in only small amounts. The total amino acid content was higher in fruits harvested from young trees than in fruits harvested from middle-aged and old trees. Xiao-ling et al. (2008) reported in wheat, essential amino acid were richer lysine, threonine, phenylalanine, isoleucine, and valine. Whereas nonessential amino acid in wheat related to protein quality such us glutamic acid, and cysteine, alanine, aspartic acid, glycine, and cysteine.

For all tree ages, GABA and ALA were the most abundant amino acids in mangosteen fruit, the mean concentration of GABA between 396.6 to $556.1 \mathrm{nmo.g} \mathrm{g}^{-1} \mathrm{DW}$ and ALA range from 292.7 to $478.5 \mathrm{nmo.g}^{-1} \mathrm{DW}$ (Table 2). By contrast, Zhang et al. (2010) revealed that aspartic acid, asparagine, glutamic acid, proline, threonine, and GABA were the main amino acids in mature 'Honeycrisp' apple fruits. GABA is the most abundant amino acid in tomato fruits at the mature green stage, and the content is related to that of the total amino acids (Koike et al., 2013). It is common for the main amino acids in fruit to differ among species, because they are influence by several factors, including practical and climatic differences, cultivar, growth stage, harvest time, and storage and ripening conditions (Kim et al., 2009). The GABA content in tomato was higher in mature green and red ripe fruit (Koike et al., 2013). In the present study, we generally observed a higher total amino acid content in fruits harvested from young trees than in fruits harvested from middle-aged and old trees. 


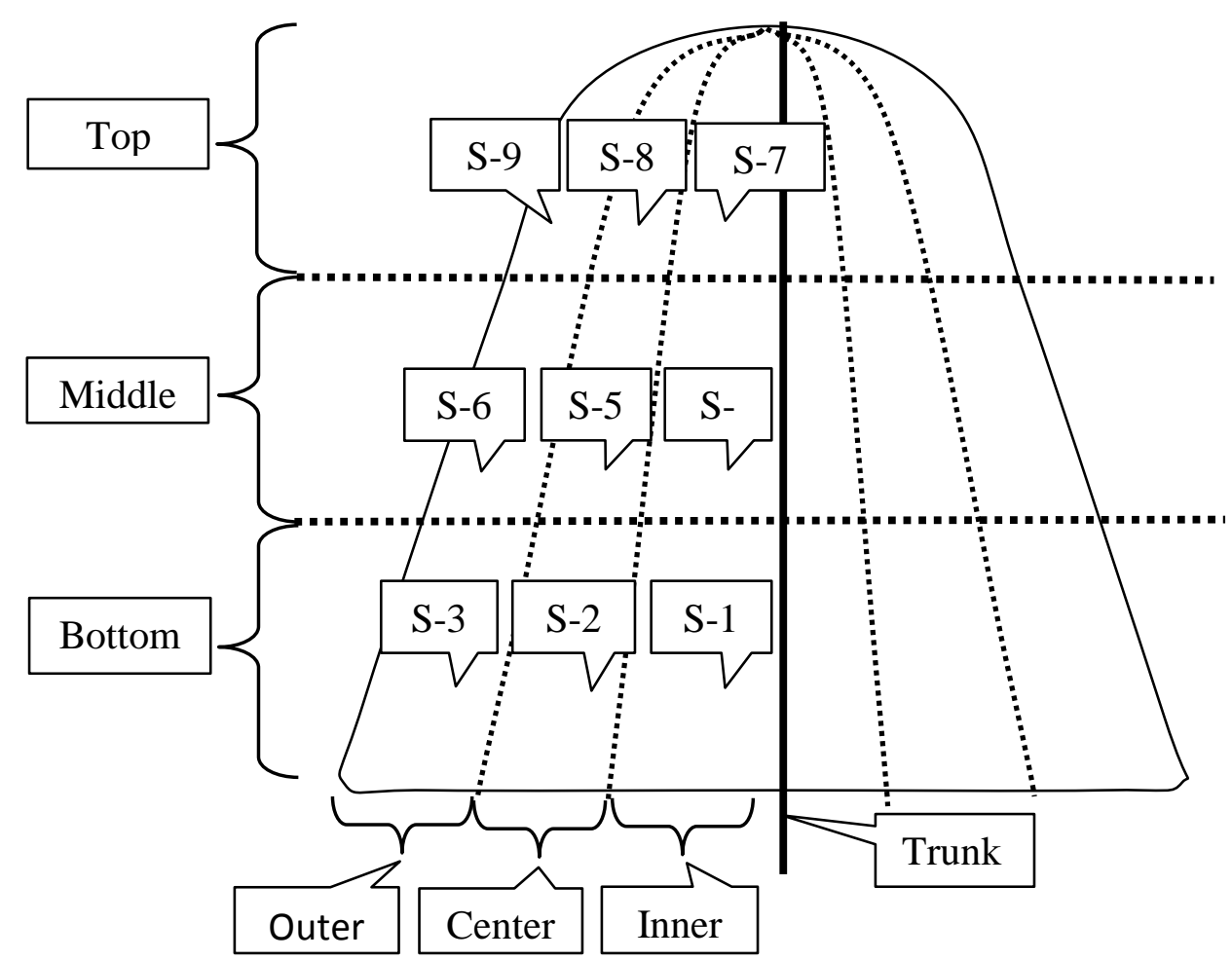

Figure 1. Illustration of the sectors (positions in the canopy, S-1 to S-9) defined for study of mangosteen trees

Table 1 Chromatography system suitability results in mangosteen fruit (aril)

\begin{tabular}{|c|c|c|c|c|c|}
\hline Standard Area & Amino acid & $\begin{array}{l}\text { Retention } \\
\text { Time (min) }\end{array}$ & Height & Area & $\begin{array}{c}\text { Amino Acid } \\
\text { Concentration } \\
\left(\mathrm{nmol} \cdot \mathrm{g}^{-1} \mathrm{DW}\right)\end{array}$ \\
\hline 1049548 & Aspartic acid (Asp) & & & & - \\
\hline 1751630 & Threonine (Thr) & 9.39 & 4857 & 145362 & 37 \\
\hline 1157891 & Serine (Ser) & 10.57 & 4071 & 82996 & 32 \\
\hline 1013966 & Glutamic acid (Glu) & 11.32 & 2509 & 66268 & 29 \\
\hline 2112963 & Glycine (Gly) & 16.05 & 5941 & 211031 & 45 \\
\hline 1123782 & Alanine (Ala) & 17.37 & 19412 & 895504 & 357 \\
\hline 1140670 & Cysteine (Cys) & 19.72 & 1023 & 18,484 & 7 \\
\hline 1113651 & Valine (Val) & 20.45 & 7981 & 224427 & 90 \\
\hline 1099864 & Isolecine (Ile) & 25.68 & 3643 & 273918 & 112 \\
\hline 1095828 & Leucine (Leu) & 27.55 & 3273 & 144168 & 59 \\
\hline 999514 & Tyrosine (Tyr) & 29.55 & 4167 & 177264 & 80 \\
\hline 1060647 & Phenylalanine (Phe) & 30.56 & 4310 & 110775 & 47 \\
\hline 1020555 & $\gamma$-aminobutyric acid (GABA) & 31.93 & 96186 & 1688961 & 742 \\
\hline 1217903 & Lysine (Lys) & 33.91 & 2627 & 52661 & 19 \\
\hline 1130106 & Histidine (His) & 37.03 & 924 & 23531 & 9 \\
\hline 1002425 & Arginine (Arg) & 42.84 & 1345 & 60480 & 27 \\
\hline
\end{tabular}


Table 2 Amino acid content and composition in mangosteen fruits harvested at mature green stage as affected by different trees aged

\begin{tabular}{lccc}
\hline \multirow{2}{*}{ Amino acid } & \multicolumn{3}{c}{ Amino acid composition (nmol.g $\left.{ }^{-1} \mathrm{DW}\right)$} \\
\cline { 2 - 4 } & \multicolumn{1}{c}{ Young age } & Middle age & Old age \\
\hline -aminobutyric acid (GABA) & $556.1 \pm 3.1 \mathrm{a}$ & $447.5 \pm 4.8 \mathrm{ab}$ & $396.6 \pm 4.10 \mathrm{~b}$ \\
Alanine (Ala) & $478.5 \pm 6.4 \mathrm{a}$ & $336.3 \pm 4.5 \mathrm{~b}$ & $292.7 \pm 3.7 \mathrm{~b}$ \\
Isoleucine (Ile) & $60.7 \pm 5.1$ & $92.1 \pm 2.7$ & $88.8 \pm 2.27$ \\
Valine (Val) & $70.7 \pm 2.6$ & $63.6 \pm 3.3$ & $59.7 \pm 2.05$ \\
Glycine (Gly) & $41.7 \pm 3.6$ & $23.4 \pm 3.7$ & $34.9 \pm 3.53$ \\
Phenylalanine (Phe) & $40.0 \pm 4.8$ & $34.0 \pm 4.0$ & $32.3 \pm 5.06$ \\
Leucine (Leu) & $37.1 \pm 5.4$ & $34.6 \pm 3.9$ & $32.6 \pm 4.92$ \\
Tyrosine (Tyr) & $34.7 \pm 4.2$ & $36.2 \pm 5.8$ & $24.8 \pm 5.72$ \\
Serine (Ser) & $59.1 \pm 3.4 \mathrm{a}$ & $22.5 \pm 5.0 \mathrm{~b}$ & $14.5 \pm 2.02 \mathrm{~b}$ \\
Arginine (Arg) & $15.9 \pm 2.1$ & $17.2 \pm 1.7$ & $13.7 \pm 4.10$ \\
Other * & $115.7 \pm 3.2 \mathrm{a}$ & $58.7 \pm 4.7 \mathrm{~b}$ & $52.5 \pm 3.59 \mathrm{~b}$ \\
\hline Total & $1510.2 \pm 8.3 \mathrm{a}$ & $1166.6 \pm 9.0 \mathrm{ab}$ & $1042.7 \pm 8.61 \mathrm{~b}$ \\
\hline
\end{tabular}

Value with different letters in each row indicate significant difference by Duncan's Multiple Range Test, $p<0.05$. Note: * Other $=$ Lysine $($ Lys $)+$ Threonine $(\mathrm{Thr})+$ Glutamic acid $($ Glu $)+$ Cysteine $($ Cys $)+$ Metionine $($ Met $)+$ Histidine $($ His $)+$ Aspartic acid (Asp) + Asparagine (Asn).

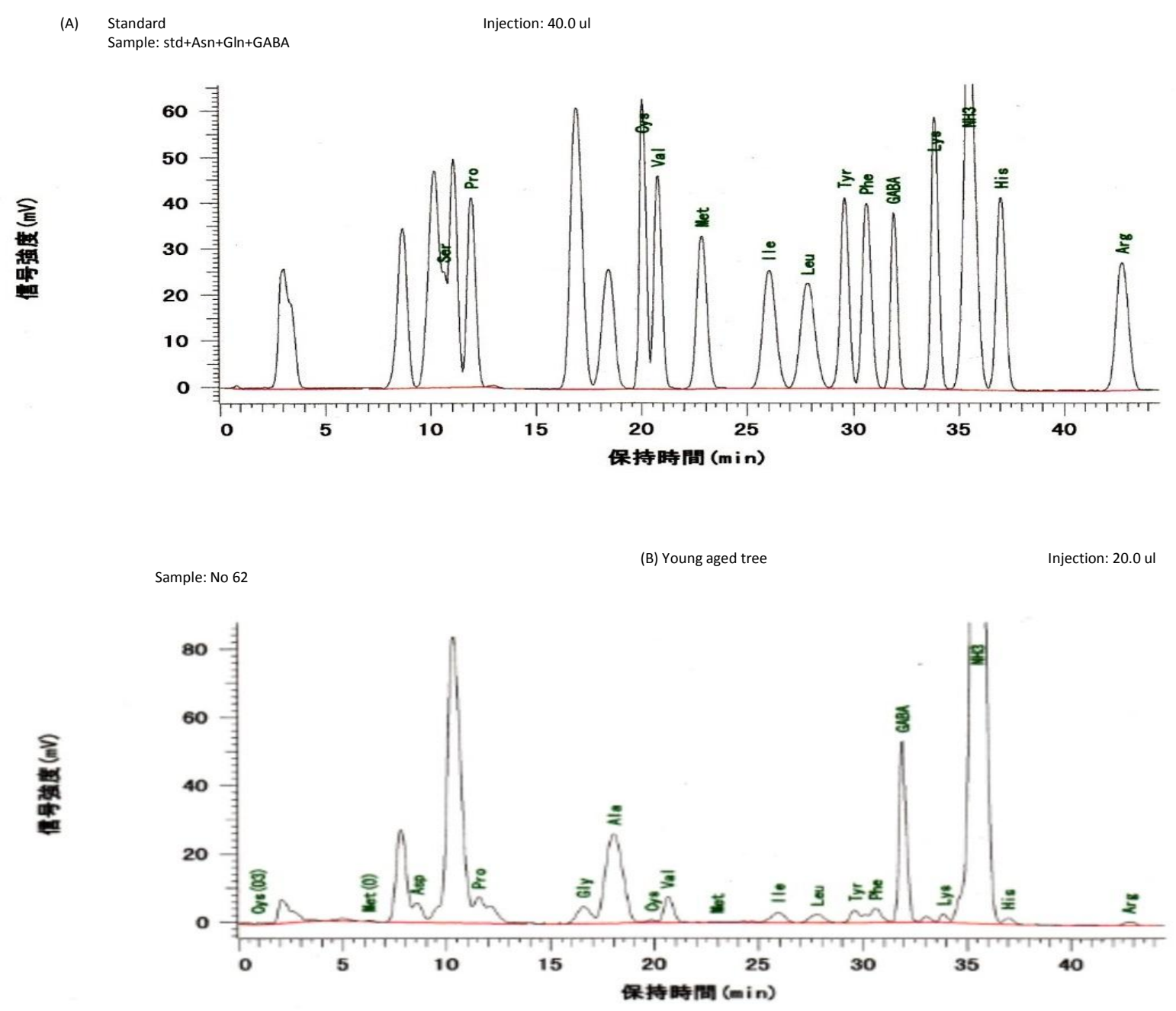




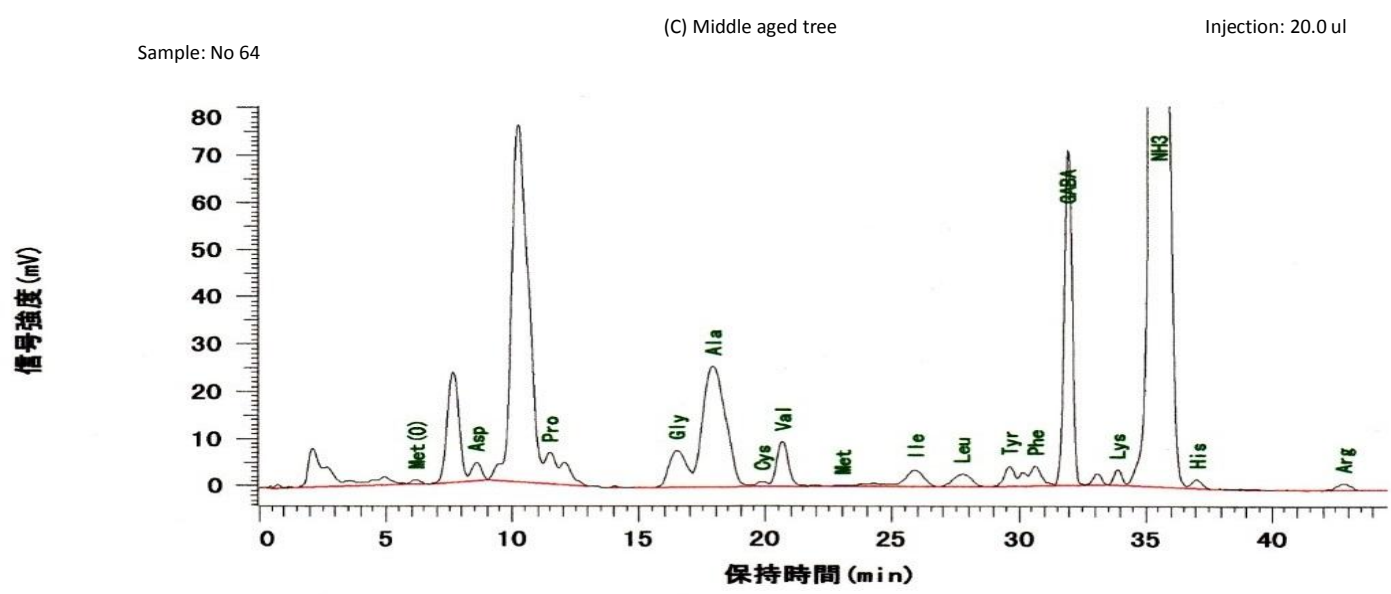

$\begin{array}{lll}\text { Sample: No. } 73 & \text { (D) Old aged tree } & \text { Injection: } 20.0 \mathrm{ul}\end{array}$

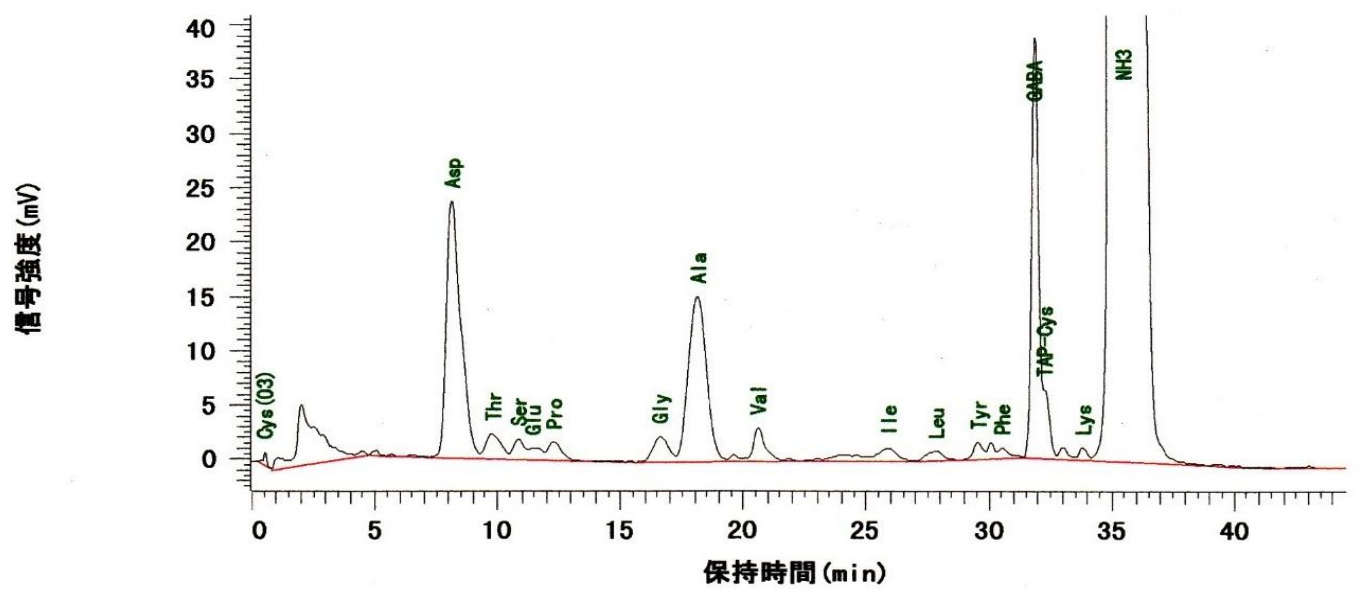

Figure 2. HPLC chromatogram of mangosteen fruit aril extract, (a) standard, (b) young, (c) middle, (d) old aged tree

In conclusion, we have demonstrated marked variations in the content and composition of amino acids of mature green mangosteen fruit (aril) harvested from different tree ages. In particular, fruits harvested from young trees (putative 20 years old) showed more total amino acid. The reasons for these variations in amino acid content remain to be elucidate

\section{REFERENCES}

Barboni, T., M. Cannac, N. Chiaramonti. 2010. Effect of cold storage and ozone treatment on physicochemical parameters, soluble sugars and organic acids in Actinidia deliciosa. Food Chem. 121: 946-951.

Barbosa, J.M., N.K., Singh, J.H. Cherry, R.D. Locy. 2010. Nitrate uptake and utilization is modulated by exogenous $\gamma$-aminobutyric acid in Arabidopsis thaliana seedlings. Plant Physiol. Biochem. 48: 443450.

Bor, M., B. Seckin, R. Ozgur, O. Yilmaz. 2009. Comparative effects of drought, salt, heavy metal and heat stresses on gamma-aminobutryric acid levels of sesame (Sesamum indicum L.). Acta Physiol. Plant 31:655-659.

Diczbalis, Y. 2009. Farm and forestry production and marketing profile for mangosteen (Garcinia mangostana L.). p. 1-14. In Elevitch, C.R. (Eds.). Specialty crops for Pacific Island agroforestry. Permanent Agriculture Resources (PAR). Holualoa.

Huang, T., G. Jander, M. de Vos. 2011. Non-protein amino acids in plant defense against insect herbivores: Representative cases and opportunities for further functional analysis. Phytochem. 72: 1531-1537.

Jia, H., G. Okamoto, K. Hirano. 2000. Effect of amino acid composition on the taste of 'Hakuho' peaches (Prunus persica Batsch) grown under different fertilizer levels. J. Japan. Soc. Hort. Sci. 69: 135-140.

Khalid, S., A.U. Malik, B.A. Saleem, A.S. Khan, M.S. Khalid, M. Amin. 2012. Tree age and canopy position affect rind quality, fruit quality and rind nutrient content of 'Kinnow' mandarin (Citrus nobilis 
Lour $\times$ Citrus deliciosa Tenora). Sci. Hort. 135: 137144.

Kim, Y.K., H. Xu, N.I. Park, H.O. Boo, S.Y. Lee, S.U. Park. 2009. Amino acid and GABA content in different cultivars of Momordica charantia L. J. Medic. Plants Rec. 3(11): 897-900.

Koike, S., C. Matsukura, M. Takayama, E. Asamizu, H. Ezura. 2013. Suppression of $\gamma$-aminobutyric acid (GABA) transaminases induces prominent GABA accumulation, dwarfism and infertility in the tomato (Solanum lycopersicum L.). Plant Cell Physiol. 54(5):793-807.

Misra, H., B.K. Dwivedi, D. Mehta, B.K. Mehta, D.C. Jain. 2009. Development and validation of high performance thin-layer chromatographic method for determination of $\alpha$-mangostin in fruit pericarp of mangosteen plant (Garcinia mangostana L.) using ultraviolet - visible detection. Rec. Nat.

Palapol, Y., S. Ketsa, D. Stevenson, J.M. Cooney, A.C. Allan, I.B. Ferguson. 2009. Colour development and quality of mangosteen (Garcinia mangostana L.) fruit during ripening and after harvest. Postharvest Biol. Technol. 51: 349-353.

Pothitirat, W., W. Gritsanapan. 2009. HPLC quantitative analysis method for the determination of $\alpha$-mangostin in mangosteen fruit rind extract. Thai J. Agri. Sci. 42(1): 7-12.

Setiawan, E., R. Poerwanto. 2008. Produktivitas dan Kualitas Buah Manggis (Garcinia manggostana L.) di Purwakarta. J. Agrovigor 1(1): 12-20.
Setiawan, E., R. Poerwanto, F. Fukuda, N. Kubota. 2012a. Meteorological conditions of mangosteen orchard in West Java, Indonesia and seasonal changes in C-N ratio of their leaves as affected by sector (position in canopy) and tree age. Sci. Rep. Fac. Agr. Okayama Univ. 101: 39-47.

Setiawan, E., Poerwanto, R., F. Fukuda, N. Sugiyama, K. Saitoh, N. Kubota. 2012b. Effect of sector (position in canopy) on allocation of ${ }^{13} \mathrm{C}$-photosynthates in mangosteen. J. Agron. Indonesia 40:139-145.

Setiawan, E. 2013. Flowering phenology of mangosteen (Garcinia mangostana L.) in Indonesia. J. Rekayasa 6(1): 1-5.

Setiawan, E. 2014. Relationship between mangosteen leaf nitrogen contents and leaf spad values. J. Agrovigor $7(1): 1-6$.

Xiao-ling, J., T. Ji-chun, H. Zhi, Z. Wei-dong. 2008. Protein content and amino acid composition in grains of wheat-related species. Agri. Sci. in China. 7(3): 272279.

Xing, S.G., Y.B. Jun, Z.W. Hau, L.Y. Liang. 2007. Higher accumulation of $\gamma$-aminobutyric acid induced by salt stress through stimulating the activity of diamine oxidases in Glycine max (L.) Merr. roots. Plant Physiol. Biochem. 45: 560-566.

Zhang, Y., P. Li, L. Cheng. 2010. Developmental changes of carbohydrates, organic acids, amino acids, and phenolic compounds in 'Honeycrisp' apple flesh. Food Chem. 123: 1013-1018. 